\title{
Corruption, production structure and economic development in developing countries
}

\author{
Helis Cristina Zanuto Andrade Santos \\ and Gilberto Joaquim Fraga
}

\begin{abstract}
Corruption has reached alarming levels in recent years and now costs the equivalent of about $5 \%$ of global output annually. Given this backdrop, this study sets out to investigate how corruption and the production structure affects the socioeconomic development of developing countries, applying a dynamic panel data procedure to the period 2002-2014. The main findings include the fact that the relation between corruption and development is non-linear. The study of the different dimensions of development also needs to encompass both economic and social perspectives. In general, there are signs that a more sophisticated production structure distorts the effects of corruption control by strengthening the influence of corruption itself on socioeconomic development.
\end{abstract}

\section{Keywords}

Corruption, corporate corruption, economic aspects, production, productivity, economic development, social development, economic analysis, developing countries

JEL classification

O11, O50, E00

\section{Authors}

Helis Cristina Zanuto Andrade Santos is a doctoral candidate in Economics of Industry and Technology at the Federal University of Rio de Janeiro (Brazil), and a substitute professor in the Department of Economics at the State University of Maringá (UEM) (Brazil). The author gratefully acknowledges the support of the National Council for Scientific and Technological Development (CNPq) in preparing this article, which was written while she was studying for her master's degree (2015-2016). E-mail: helis_czas@hotmail.com.

Gilberto Joaquim Fraga is Associate Professor in the Department of Economics at the State University of Maringá (UEM) (Brazil). E-mail: gjfraga@uem.br.

Comments on the first version of this text made by anonymous referees are gratefully acknowledged. Nonetheless, this final version is the authors' exclusive responsibility. 


\section{Introduction}

Globalization and the speed with which information is disseminated have made it possible to detect greater signs of corruption, which have fuelled concern among the authorities and given rise to research on this subject. Each year, the cost of corruption represents more than $5 \%$ of global gross domestic product (GDP), equivalent to US\$2.6 trillion. According to the World Economic Forum (2012), more than US\$ 1 trillion is paid in bribes. In this context, many researchers, both academic and non-academic, have been analysing both the determinants of corruption and its effects on the growth and development of economies.

One of the earliest studies on the subject is that of Leff (1964), who considers that corruption can have a positive influence, by "lubricating the wheels" of economic growth. The most recent studies have also focused on spending on sophisticated technologies in countries that probably do not need them, and on the sophistication of the production structure, which have been suggested as some of the potential drivers of corruption. In this connection, Shleifer and Vishny (1993) and Rose-Ackerman (1997) have made important theoretical contributions to the area of study that relates corruption to the sophistication of the production structure and economic development.

Shleifer and Vishny's (1993) theoretical model considers the supply of and demand for government goods by private agents, both at a normal price to be charged and at a price that includes a bribe. The authors argue that poor countries prefer to spend their resources on infrastructure and defence projects, which offer greater opportunities for corruption, than on improvements in education and health. As for new technologies, these could be concentrated in monopolies or oligopolies to ensure the continuity of bribery and embezzlement. In this case, new firms face entry barriers and there are obstacles to innovation, which undermine investments and growth in the economy. Rose-Ackerman (1997) argues that corruption can have a positive influence and that, in some cases, bribes and kickbacks may not impose costs on society. However, once a person succumbs to these, he/she is likely to become increasingly corrupt, and eventually negative impacts will make themselves felt.

Although the literature contains various studies that attempt to explain development, there is a gap in terms of the joint effects of the production structure and corruption in terms of improving national living standards. This makes it important to analyse the simultaneous effects of the country's production structure and corruption on development.

With this as a backdrop, this study sets out to analyse the relation between corruption, the production structure and development. It also examines the potential effects of the interaction between corruption and the country's production structure on the socioeconomic development of developing countries.

In this study, social development is proxied by the percentage of the population that suffers from undernutrition; and economic development is measured by the logarithm of per capita GDP. Corruption is represented by the control-of-corruption indicator. The production structure is represented by the sectoral outputs of manufacturing industry, agriculture and services, together with the economic complexity index. The empirical estimation controls for other effects, such as the level of human capital, foreign investment and drinking water. The estimations are conducted using the dynamic panel data procedure.

The article is divided into five sections, including this introduction. While section II presents the empirical literature, the next section describes the data and the empirical strategy used, and section IV details and discusses the econometric estimates. The fifth and last section offers final thoughts. 


\section{Empirical literature}

This section discusses a number of empirical studies that address the relation between corruption, the production structure and development. Authors examining the effects of corruption on development include Akçay (2006), Sodré (2014) and Dalberto (2016), who obtained econometric results suggesting a negative relationship between corruption and development or growth. Some results also suggest that corruption is likely to intensify income concentration and inequality and increase poverty.

Other research suggests that the effects of corruption can be represented graphically as U-shaped or non-linear. Li, Xu and Zou (2000) find that income inequality is lower at either high or low levels of corruption, whereas a medium level of corruption is associated with high income inequality. Houston (2007) performs an exhaustive analysis of the effects of corruption on economic growth, to verify whether these are expansionary or restrictive, and concludes that they can be either, depending on the degree to which the country's property protection laws are enforced. Aidt, Dutta and Sena (2008) study the non-linear effects of this relationship and differences in institutional quality. In countries with high-quality political institutions, corruption has an adverse effect on growth, while in countries where institutional quality is low, corruption has no effect on output. This evokes the idea of corruption as a "lubricant for the wheels of economic growth".

Analysis by Swaleheen (2011) suggests that corruption has both a direct and an indirect effect on growth, depending on the level of corruption in the country in question. Along the same lines, Sobral (2014) explains that the relationship between the variables may not be linear in the case of countries with greater civil liberty.

The various studies use different criteria to measure the effects of the production structure on development. For example, Hartmann and others (2015) use the economic complexity index as a proxy for production sophistication and the Gini coefficient of output. The authors find that, in addition to contributing to economic growth, increased economic complexity is accompanied by a reduction in income inequality.

Mauro (1997b and 1998) reports that corrupt governments find it easier to collect bribes on some types of expenditure than on others. Large projects that are difficult to value, such as infrastructure or high-tech defence systems, are likely to be more susceptible to corruption than teachers' wages for example, which alters the composition of government expenditure, specifically by reducing spending on education. Ruhashyankiko and Yehoue (2006) suggest that technology-driven expansion of the private sector leads to a reduction in aggregate corruption, and that a reduction in public corruption could outweigh a possible increase in its private counterpart.

Mahdavi (2014) documents the existence of a relationship between corruption and countries with an oil-oriented production structure only when countries establish national oil regulatory agencies. These agencies can facilitate corruption, as they are set up with political guidelines, and their officials have greater opportunities to solicit bribes. In addition to fluid political connections, there is also a greater propensity for corruption, as these managers handle the oil licenses and access to contracts, and can make them more lucrative.

Leite and Weidmann (1999) use a growth model to analyse the relations that exist between natural resources, corruption and economic growth. The authors find that the adverse effects of corruption on economic growth are non-linear: the effects are intensified in less developed countries, and natural resource abundance creates opportunities for rent-seeking activities, which in turn fosters corruption.

Lastly, a study by the Organization for Economic Cooperation and Development (OECD, 2013) reviews specific cases of countries with high economic growth in unfavourable environments. ${ }^{1}$ As countries such as the Republic of Korea and areas such as Taipei, China, move into the high-income

\footnotetext{
1 Rock and Bonnett (2004) explain that corruption reduces growth in most developing countries, especially in small ones, but boosts growth in the larger newly industrialized East Asian countries.
} 
group, they are seeing improvements in their corruption levels. This situation may indicate that, while the levels of corruption remained high as these economies attained higher levels of technology, the production structure may have mitigated the perverse effects of corruption in that period, since they succeeded in achieving high growth in that environment.

\section{Data and empirical strategy}

\section{Database and description of variables}

To achieve the proposed objectives, the study used panel data on 98 developing countries (listed in annex A1) spanning 2002-2014.

Two proxy variables were chosen, one for the production structure and another for corruption. The sophistication of the production structure is represented by the economic complexity index (ECl) and by the GDP shares of manufacturing industry, agriculture and services. ${ }^{2}$ Corruption is represented by the control-of-corruption (CC) indicator, which is based on the strength of the country's governance. ${ }^{3}$ The interaction between the CC indicator and each of the production structure proxies is discussed below to test the significance of each result.

According to the empirical literature, the variables are defined and interpreted as follows: ${ }^{4}$

(i) loggdp: "Logarithm of GDP per capita (constant 2010 US\$)" - the higher the loggdp value, the greater the expected level of development;

(ii) sub: "Percentage of population who are undernourished", which is below the minimum level of dietary energy consumption (United Nations, $\mathrm{n} / \mathrm{da}$ and $\mathrm{n} / \mathrm{db})^{5}$-the higher the value of sub, the lower the expected level of development;

(iii) eci: "Economic complexity index", which represents the complexity of the country's products (OEC, $\mathrm{n} / \mathrm{da}$ and $\mathrm{n} / \mathrm{dc}$ ) -the higher the eci value, the higher the levels of sophistication of production and loggdp and the lower the level of sub;

(iv) gdpagro: "Agriculture, value-added (\% of GDP)" - the higher the gdpagro value, the lower the sophistication of production relative to the industry share of GDP and the lower the value of sub;

(v) gdpind: "Industry, value-added (\% of GDP)" - the higher the value of gdpind, the greater the production sophistication with respect to the agriculture and services sectors of GDP, the greater the expected values of both loggdp and sub;

(vi) gdpser: "Services and others, value-added (\% of GDP)" - the higher the gdpser value, the lower the productive sophistication with respect to the industry's share of GDP, the higher the value of loggdp and the lower the value of sub;

2 Although the $\mathrm{ECl}$ variable is used to represent a given country's knowledge, it is constructed according to the ubiquity and diversity of the products that it exports. The variable will represent a more complex economy or one with a knowledge-sophisticated production structure. For further information see the Atlas by Hausmann and others (2011). When considering sectoral GDPs, the sophistication of the production structure will be understood in terms of technology or machinery.

3 This indicator measures perceptions of the extent to which corruption has been controlled in the country. The lower its value, the less control the country has over corruption, in other words the greater the perception of corruption. It is built on the perception of public authority exercised for private gain, including small and large forms of corruption and elite interests (Kaufmann, Kraay and Mastruzzi, 2010; World Bank, n/dc).

4 Some estimates used the World Bank indicators Domestic credit provided by the financial sector (as a percentage of GDP) and High-tech exports (as a percentage of manufacturing exports) (World Bank, n/da), which are also the source of the variables for items (i), (iv), (v), (vi), (viii), (ix) and (xii).

5 This is calculated using the minimum dietary energy requirement, which varies according to gender, age and different levels of physical activity (FAO, 2016). According to data available from FAO (2016) for various countries, the minimum food energy requirement ranged from 1,654 kilocalories per person per day for Timor-Leste to 1,987 kilocalories per person per day for the United Arab Emirates over the period 2014-2016. The values for the least developed countries and the world as a whole were, respectively, 1,747 and 1,844 kilocalories per person per day. 
(vii) controlcorrup: "Control of corruption" (World Bank, $\mathrm{n} / \mathrm{db}$ and $\mathrm{n} / \mathrm{dc}$ ) - the higher the controlcorrup value, the lower the level of corruption, the higher the value of loggdp and the lower the value of sub;

(viii) abecom: "Trade (\% of GDP)" - the higher the value of abecom, the greater the trade openness, the higher the value of loggdp and the lower the value of sub;

(ix) fdii: "Foreign direct investment (FDI), net inflows (\% of GDP)" - the higher the value of fdii, the higher the net inflow of FDI, the higher the value of loggdp and the lower the value of sub;

(x) water: "Proportion of population using improved drinking water sources, total" (United Nations, $\mathrm{n} / \mathrm{da}$ ) - the higher the value of water, the higher the proportion of the population using improved drinking water sources, the higher the value of loggdp and the lower the value of sub;

(xi) hc: "Human capital index, based on years of study and return to education" (Feenstra, Inklaar and Timmer, 2015) - the higher the value of $h c$, the higher the human capital index, the higher the value of loggdp and the lower the value of sub;

(xii) gini: "Gini index" - the higher the gini value, the greater the income inequality and the greater the value of sub;

(xiii) ores_metal: "Minerals and metals (\% share of exports)" (WITS, 2018) -the higher the ores_metal value, the greater the abundance of non-agricultural commodities, the higher the values of both loggdp and sub;

The descriptive statistics of the variables are presented in table 1.

Table 1

Descriptive statistics, 2002-2014

\begin{tabular}{lrrrrr}
\hline Variable (global) & Media & Standard deviation & Minimum & Maximum & Comments \\
\hline sub & 14.99677 & 11.20825 & 5 & 53.5 & $\mathrm{~N}=1144$ \\
\hline loggdp & 8.032544 & 1.330887 & 5.268729 & 11.22033 & $\mathrm{~N}=1272$ \\
\hline controllcorrup & 0.3610675 & 0.1279468 & 0 & 0.75 & $\mathrm{~N}=1274$ \\
\hline eci & -0.3656327 & 0.76884 & -3.17674 & 1.86034 & $\mathrm{~N}=1074$ \\
\hline gdpind & 32.57637 & 13.80958 & 6.896044 & 77.41366 & $\mathrm{~N}=1173$ \\
\hline gdpagro & 15.25261 & 12.21122 & 0.0344685 & 58.20515 & $\mathrm{~N}=1175$ \\
\hline gdpser & 52.15547 & 12.53512 & 18.90939 & 92.98227 & $\mathrm{~N}=1171$ \\
\hline corceci & -0.1025409 & 0.3013437 & -0.9692 & 1.395255 & $\mathrm{~N}=1074$ \\
\hline corind & 11.73966 & 6.391206 & 0 & 45.2799 & $\mathrm{~N}=1173$ \\
\hline coragro & 5.066135 & 4.306053 & 0 & 27.06063 & $\mathrm{~N}=1175$ \\
\hline corser & 19.50751 & 10.37118 & 0 & 69.7367 & $\mathrm{~N}=1171$ \\
\hline abecom & 87.028 & 57.6045 & 19.11879 & 455.2767 & $\mathrm{~N}=1240$ \\
\hline fdii & 4.817579 & 7.002263 & -8.400837 & 89.47596 & $\mathrm{~N}=1256$ \\
\hline cre & 47.5557 & 42.93937 & -114.6937 & 236.1799 & $\mathrm{~N}=1231$ \\
\hline tech & 8.173824 & 12.39399 & 0 & 74.17846 & $\mathrm{~N}=1098$ \\
\hline water & 82.90496 & 16.30681 & 33 & 100 & $\mathrm{~N}=1231$ \\
\hline hc & 2.234161 & 0.5793039 & 1.088122 & 3.593633 & $\mathrm{~N}=1105$ \\
\hline gini & 43.10034 & 9.424866 & 24 & 59.5 & $\mathrm{~N}=291$ \\
\hline ores_metal & 9.430601 & 15.58277 & 0 & 86.42 & $\mathrm{~N}=1131$ \\
\hline corcon & 0.1467273 & 0.1076587 & 0 & 0.5625 & $\mathrm{~N}=1274$ \\
\hline Source:Prepar & & &
\end{tabular}

Source: Prepared by the authors.

Note: Not all countries report data on all variables. Twenty-four countries report data for the gini variable: Argentina, Armenia, Belarus, Brazil, Colombia, Costa Rica, Dominican Republic, Ecuador, El Salvador, Georgia, Honduras, Kazakhstan, Mexico, Panama, Paraguay, Peru, the Plurinational State of Bolivia, Republic of Moldova, Russian Federation, Serbia, Thailand, Turkey, Ukraine and Uruguay. The following countries are missing for the following variables: sub : Bahamas, Bahrain, Burundi, Democratic Republic of the Congo, Hong Kong (SAR of China), Libya, Papua New Guinea, Qatar, Singapore and Sudan; eci and corceci, Bahamas, Brunei Darussalam, Burundi, Democratic Republic of the Congo, the Gambia, Guinea-Bissau, Guyana, Sierra Leone and Suriname; gdpind, gdpagro, gdpser, corind, coragro and corser, Angola, Bahrain, Democratic Republic of the Congo, Kuwait, Liberia and Libya; fdii, Cuba; cre, Cuba and Iran; tech, Angola, Guinea-Bissau, Liberia, Libya and; variable water, Brunei Darussalam, Hong Kong (SAR) and Libya; hc, Azerbaijan, Bahamas, Belarus, Cuba, Democratic Republic of the Congo, Georgia, Guinea, Guinea-Bissau, Guyana, Lebanon, Libya, Oman, Papua New Guinea and Suriname; ores_metal, Liberia. 
The mean values of the sub and loggdp variables for the selected sample of countries are 14.997 and 8.033, respectively, while controlcorrup has a mean of 0.361. For the production structure, eci, gdpind, gdpagro and gdpser display mean values of $-0.366,32.576,15.253$ and 52.156 , respectively. When these variables interact with controlcorrup, the mean values of their respective interactions become $-0.103,11.740,5.066$ and 19.508 .

In many African and Central American countries, a large proportion of the population was undernourished in 2014 (United Nations, n/da). Of these developing countries, Haiti had the highest percentage of undernourished population, with $52.3 \%$ of its population below the minimum level of dietary energy consumption.

Data on per capita GDP growth by region (World Bank, n/da) show that, in Africa and Central America, undernutrition data coincide with low levels of per capita GDP in 2014. Overall, South Asia seems to differ significantly when comparing these indicators, as this region has the highest trend in per capita GDP growth (5.4\% in 2014) but also high rates of undernutrition. The differences that emerge when comparing socioeconomic development indicators are due to various factors, such as the methodology used to calculate the indicator or the different characteristics of the countries in question. The characteristics of a South Asian country are likely to differ significantly from those of another country in the same group and will tend to be captured by one indicator rather than another.

In view of this, an analysis of corruption and the production structure can contribute to a better understanding of the characteristics of these countries and the values of their development indicators. In 2014, Latin America and the Caribbean, Africa and some areas of Asia seemed to have the lowest levels of corruption control. Sudan was the country with the least control of corruption, while Sweden was among the least corrupt (World Bank, $\mathrm{n} / \mathrm{db}$ ).

Figure 1 depicts the relationship between ECl and per capita GDP in 2014. Although countries with high levels of output relative to their number of inhabitants have high levels of per capita GDP, income may be highly concentrated. So, when analysed individually, per capita GDP can give a misleading picture of the country's real standard of living, hence the importance of observing the rate of undernutrition as well.

Figure 1

Selected developing countries: comparison of the economic complexity index and per capita GDP, 2014

(US dollars at constant 2010 prices)

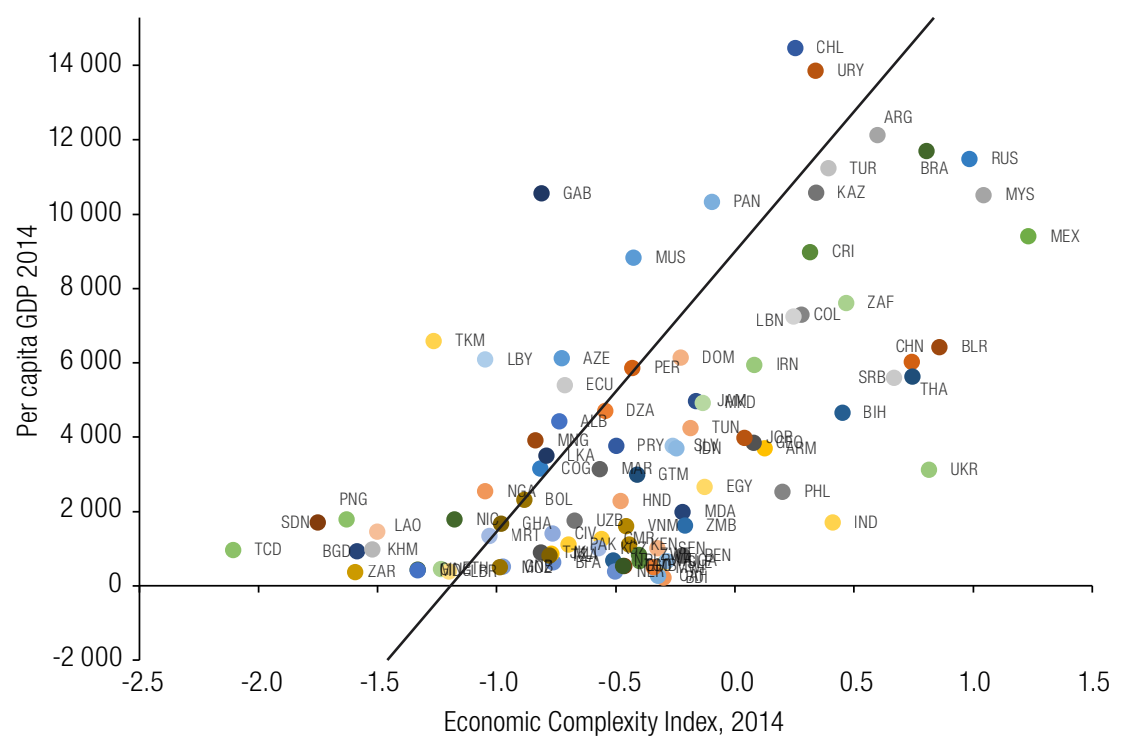

Source: Prepared by the authors, on the basis of information from The Observatory of Economic Complexity (OEC), "Economic complexity rankings", Cambridge, Massachusetts Institute of Technology (MIT), n/da [online] https://oec.world/en/rankings/country/eci/. Note: Data refer to the 98 developing countries listed in annex A1. 
In 2014, the most economically complex country was Japan, while South Sudan was the least economically complex (OEC, n/da).

This brief presentation and comparison of a number of indicators reveals the need for different proxy variables to interpret the behaviour of the economies. Accordingly, the following sections perform econometric estimations and tests, focusing on social and economic development.

\section{Empirical strategy}

Aidt, Dutta and Sena (2008) analyse the role of political accountability as a determinant of corruption and economic growth. By treating corruption as an endogenous and non-linear variable associated with differences in institutional quality, the authors find that the relation between corruption and growth is specific to the governance regime. The study's empirical contributions are as follows: the way regimes are chosen for different sets of countries; the proposal of a model that allows for threshold effects and obtains results for the consequences of corruption on growth; the estimation of the impact of growth on corruption; the introduction of non-linearities in the corruption-growth relation; differentiation between short- and long-term growth rates and the use of instrumental variables. It is argued that the links between corruption, growth and institutions may not be straightforward, so non-linear and reverse-causality effects should be considered.

Accordingly, an empirical dynamic panel model is proposed for this study, inspired by Aidt, Dutta and Sena (2008). The model treats corruption as an interaction variable with respect to the production structure (there may be reverse causality); and attention will be paid to any differences in structure that may exist. The generalized method of moments (GMM) methodology is chosen as it allows for the use of instrumental variables. Subsequently, potential non-linearity effects will also be considered. The empirical model to be estimated is represented in equation 1:

$$
D E_{i t}=\alpha_{0}+\lambda D E_{i t-1}+\beta_{1} \sum_{i=1}^{3} P S_{i t}+\beta_{2} C_{i t}+\beta_{3} C \sum_{i=1}^{3} P S_{i t}+\beta_{4} C V_{i t}+\mu
$$

Development $(D E)$ is the variable to be explained, as a function of its lagged effects, the control variables $(\mathrm{CV})$, the selected variables of interest and the error term $(\mu)$. Economic development will be measured by (loggdp), and social development will be denoted by (sub). The country's development is slow to transition over time, and past development influences the current stage of development. Because its evolution depends on institutional and social characteristics that do not change frequently, the use of the dynamic panel is appropriate. Depending on the type $i$ of production structure (PS) that predominates in the country (agriculture, manufacturing industry or services), the relationship with development can be differentiated by assuming a greater or lesser sophistication in that structure. A predominantly industrial production structure can be represented by the measure (eci).

Corruption $(C)$ is measured by the control-of-corruption indicator (controlcorrup), which is expected to be positively related to socioeconomic development. As is generally suggested in the literature, the greater the control of corruption, the lower the perception of corruption in the country, which thus improves socioeconomic development. Accordingly, the relationship between (controlcorrup) and (loggdp) is expected to be positive, improving economic development; and the relationship between (controlcorrup) and (sub) is expected to be negative, since greater control of corruption and the resulting improvement in social development could help to reduce undernourishment.

With regard to the interaction variable relating corruption and the production structure $\left(C \sum_{i=1}^{3} P S_{i}\right)$, an inverse causality relation is suggested. On the one hand, people might be willing to choose more advanced technologies than necessary, owing to greater facility for embezzlement. In addition, some 
investment projects in more sophisticated sectors could conceal future illicit gains. Thus, an attempt to benefit through the misappropriation of funds would result in investment projects and technologies that would not necessarily be aligned with the country's production model.

On the other hand, once these technologies are implemented and a certain level of sophistication is attained in the country's production structure, actions such as project renewal and machinery and equipment replacement could increasingly stimulate corrupt behaviour and embezzlement. Thus, the following interpretation is possible: when a country has a complex production structure involving technology-intensive goods, it is harder to measure those goods compared to standard ones. For example, measuring aircraft production may be more complex than the production of motor vehicles, because there are more firms that produce and sell cars than those that manufacture aircraft. Thus, corruption could occur more easily in countries that produce more technology-intensive goods because these sectors tend to be composed of just a few firms (oligopolies), and the prices of equipment needed for production may be overestimated (see Shleifer and Vishny, 1993; Hines, 1995; Mauro, 1997b and 1998; and Rose-Ackerman, 1997).

It can therefore be seen that the development effects of corruption can be enhanced or mitigated through the sophistication of the production structure. These effects will be analysed in the econometric model by interpreting the sign of the interaction variable. The relation between this variable and socioeconomic development is expected to be ambiguous: the more complex the country's production structure, the greater the opportunities for embezzlement and bribery, which generate more corruption and less development. However, if there is no joint influence between corruption, the sophistication of the production structure and the country's development, or if that relationship is weak, the effects of corruption will not prevail, resulting in an improvement in development the more sophisticated are the goods produced, even when corruption exists.

That said, the interaction variable between the indicator (controlcorrup) and measures of the production structure (PS) can be either negatively related to development -if the greater sophistication of the production structure boosts corruption, so that the influence of greater corruption control is diminished and ultimately reduces socioeconomic development - or else positively related, if there is no joint influence or if the greater sophistication of the production structure mitigates the effects of corruption itself on development, such that greater corruption control enhances development.

The specification of the empirical model and description of the database show that this is a panel data estimation. The advantages of this procedure, as discussed in Baltagi (2005), include the ability to control for heterogeneous effects in each country or individual. They also provide more information about the data and allow greater variability, efficiency and freedom and less collinearity.

For the estimation of the dynamic panel data, Arellano and Bond (1991) and Arellano and Bover (1995) contribute to the use of GMM, which was subsequently developed further with the GMM system of Blundell and Bond (1998).

The moment, or orthogonality condition is observed in equation 2.

$$
\begin{array}{lcc}
E\left[D E_{i, t-2}\left(\mu_{i t}-\mu_{i, t-1}\right)\right]=0 & \forall & t=3, \ldots, T \\
E\left[X_{i, t-2}^{\prime}\left(\mu_{i t}-\mu_{i, t-1}\right)\right]=0 & \forall & t=3, \ldots, T
\end{array}
$$

Thus, as explained by Baltagi (2005), in the equation of first differences, $D E_{t-2}$ is a valid instrument because it is strongly correlated with $\left(D E_{i, t-1}-D E_{i, t-2}\right)$ but not correlated with $\left(\mu_{i t}-\mu_{i, t-1}\right)$. Following the estimation, tests will be performed to check for possible autocorrelation and validity problems in the instruments. 


\section{Estimations and tests}

\section{Corruption, production structure and social development}

In relating corruption and the production structure to verify its effects on social development, the specifications shown in tables 2 and 3 were estimated, using the percentage of the population who are undernourished as dependent variable.

Table 2

Selected developing countries (88): basic dynamic panel model with undernutrition as dependent variable, 2002-2014

\begin{tabular}{|c|c|c|c|c|c|}
\hline Variables & (1) & (2) & (3) & (4) & (5) \\
\hline \multirow[t]{2}{*}{$\operatorname{sub}_{(t-1)}$} & $0.902^{\star \star \star}$ & $0.925^{\star \star \star}$ & $0.909^{\star \star \star}$ & $0.948^{\star \star \star}$ & $0.882^{\star \star \star}$ \\
\hline & $(0.00986)$ & $(0.0141)$ & $(0.0153)$ & $(0.00970)$ & $(0.0608)$ \\
\hline \multirow[t]{2}{*}{ controlcorrup } & $-0.315^{\star \star}$ & $-0.777^{\star \star \star}$ & $1.324^{\star \star}$ & & $-1.789^{*}$ \\
\hline & $(0.133)$ & $(0.163)$ & $(0.645)$ & & $(0.996)$ \\
\hline \multirow{2}{*}{ controlcorrup $_{(t-1)}$} & & & $-1.534^{\star \star}$ & & \\
\hline & & & $(0.693)$ & & \\
\hline \multirow[t]{2}{*}{ eci } & & $-0.239^{* *}$ & -0.138 & & \\
\hline & & $(0.0951)$ & $(0.118)$ & & \\
\hline \multirow[t]{2}{*}{$e c i_{(t-1)}$} & & & $-0.251^{\star \star}$ & & \\
\hline & & & $(0.128)$ & & \\
\hline \multirow[t]{2}{*}{ corceci } & & & & $0.719^{\star \star \star}$ & \\
\hline & & & & $(0.272)$ & \\
\hline \multirow[t]{2}{*}{ gini } & & & & & $0.123^{\star \star \star}$ \\
\hline & & & & & $(0.0431)$ \\
\hline \multirow[t]{2}{*}{ ores_metal } & & & & & 0.00696 \\
\hline & & & & & $(0.00784)$ \\
\hline \multirow[t]{2}{*}{ Constant } & $1.190^{\star \star \star}$ & $0.919^{\star \star \star}$ & $0.891^{\star \star \star}$ & $0.481^{\star \star \star}$ & $-3.907^{\star \star \star}$ \\
\hline & $(0.181)$ & $(0.193)$ & $(0.201)$ & $(0.141)$ & $(1.441)$ \\
\hline No. of instruments & 38 & 72 & 72 & 80 & 24 \\
\hline Sargan Test (Prob>chi²) & 0.4578 & 0.1216 & 0.1849 & 0.1527 & 0.4849 \\
\hline Arellano-Bond test (AR 2 autocorrelation) & 0.9728 & 0.7464 & 0.3945 & 0.5831 & 0.1525 \\
\hline No. of observations & 1056 & 916 & 893 & 916 & 266 \\
\hline No. of countries & 88 & 85 & 78 & 85 & 24 \\
\hline
\end{tabular}

Source: Prepared by the authors.

Note: Some estimations correspond to a smaller number of countries owing to lack of data on the explanatory variables. Twenty-four countries report data for the gini variable: Argentina, Armen)ia, Belarus, Brazil, Colombia, Costa Rica, Dominican Republic, Ecuador, El Salvador, Georgia, Honduras, Kazakhstan, Mexico, Panama, Paraguay, Peru, the Plurinational State of Bolivia, Republic of Moldova, Russian Federation, Serbia, Thailand, Turkey, Ukraine and Uruguay. The following countries are missing for the following variables: sub: Bahamas, Bahrain, Burundi, Democratic Republic of the Congo. Hong Kong (SAR of China), Libya, Papua New Guinea, Qatar, Singapore and Sudan; eci and corceci, Bahamas, Brunei Darussalam, Burundi, Democratic Republic of the Congo, the Gambia, Guinea-Bissau, Guyana, Sierra Leone and Suriname; gdpind, gdpagro, gdpser, corind, coragro and corser, Angola, Bahrain, Kuwait, Liberia and Libya; fdii, Cuba; cre, Cuba and Iran; tech, Angola, Democratic Republic of the Congo, Guinea-Bissau, Liberia and Libya; variable water, Brunei Darussalam, Hong Kong (SAR) and Libya; hc, Azerbaijan, Bahamas, Belarus, Cuba, Democratic Republic of the Congo, Georgia, Guinea, Guinea-Bissau, Guyana, Lebanon, Libya, Oman, Papua New Guinea and Suriname; ores metal, Liberia. Standard error in parentheses ${ }^{\star \star \star} p<0.01,{ }^{\star \star} p<0.05,{ }^{\star} p<0.1$ 
Table 3

Selected developing countries (88): dynamic panel with undernutrition as dependent variable, 2002-2014

\begin{tabular}{|c|c|c|c|c|c|c|}
\hline Variables & (1) & (2) & (3) & (4) & (5) & (6) \\
\hline \multirow{2}{*}{$\operatorname{sub}_{(t-1)}$} & $0.864^{\star \star \star}$ & $0.811^{\star \star \star}$ & $0.880^{\star \star \star}$ & $0.827^{\star \star \star}$ & $0.788^{\star \star \star}$ & $0.745^{\star \star \star}$ \\
\hline & $(0.0305)$ & $(0.0294)$ & $(0.0273)$ & $(0.0165)$ & $(0.0244)$ & $(0.0824)$ \\
\hline \multirow[t]{2}{*}{ controllcorrup } & $1.127^{\star \star \star}$ & $-8.069^{\star \star \star}$ & $-3.370^{*}$ & $1.891^{\star \star \star}$ & $10.39^{\star \star}$ & $-3.387^{\star \star \star}$ \\
\hline & $(0.367)$ & $(2.577)$ & $(2.027)$ & $(0.707)$ & $(4.846)$ & (1.128) \\
\hline \multirow[t]{2}{*}{ corceci } & -0.0703 & & & & & -1.756 \\
\hline & $(0.865)$ & & & & & (3.537) \\
\hline \multirow{2}{*}{ corceci $_{(t-1)}$} & $2.440^{\star \star \star}$ & & & & & $1.457^{\star \star}$ \\
\hline & $(0.797)$ & & & & & $(0.696)$ \\
\hline \multirow[t]{2}{*}{ corind } & & $0.314^{\star \star \star}$ & $0.170^{\star \star}$ & & & \\
\hline & & $(0.0859)$ & $(0.0708)$ & & & \\
\hline \multirow{2}{*}{$\operatorname{corind}_{(t-1)}$} & & $-0.0652^{\star \star}$ & $-0.0644^{\star \star}$ & & & \\
\hline & & $(0.0270)$ & $(0.0268)$ & & & \\
\hline \multirow[t]{2}{*}{ coragro } & & & & -0.0514 & & \\
\hline & & & & $(0.0476)$ & & \\
\hline \multirow[t]{2}{*}{ coragro $_{(t-1)}$} & & & & $-0.0686^{\star \star}$ & & \\
\hline & & & & $(0.0288)$ & & \\
\hline \multirow[t]{2}{*}{ corser } & & & & & $-0.158^{*}$ & \\
\hline & & & & & $(0.0919)$ & \\
\hline \multirow{2}{*}{$\operatorname{corser}_{(t-1)}$} & & & & & $-0.0344^{\star *}$ & \\
\hline & & & & & $(0.0141)$ & \\
\hline \multirow[t]{2}{*}{ eci } & 0.0698 & & & & & 0.750 \\
\hline & $(0.325)$ & & & & & (1.091) \\
\hline \multirow[t]{2}{*}{$e c i_{(t-1)}$} & $-0.633^{\star \star}$ & & & & & \\
\hline & $(0.314)$ & & & & & \\
\hline \multirow[t]{2}{*}{ gdpind } & & $-0.149^{* \star *}$ & $-0.0916^{\star \star \star}$ & -0.0165 & -0.0159 & \\
\hline & & $(0.0432)$ & $(0.0299)$ & $(0.0140)$ & $(0.0202)$ & \\
\hline \multirow[t]{2}{*}{$\operatorname{gdpind}_{(t-1)}$} & & $0.0616^{\star \star \star}$ & $0.0539^{\star \star \star}$ & $0.0319^{\star \star}$ & $0.0312^{\star \star}$ & \\
\hline & & $(0.0176)$ & $(0.0187)$ & $(0.0129)$ & $(0.0125)$ & \\
\hline \multirow[t]{2}{*}{ gdpagro } & & & $0.0335^{\star}$ & $0.0390^{\star *}$ & & \\
\hline & & & $(0.0202)$ & $(0.0190)$ & & \\
\hline \multirow[t]{2}{*}{ gdpser } & & 0.00729 & & & $0.0605^{\star}$ & \\
\hline & & $(0.0267)$ & & & $(0.0316)$ & \\
\hline \multirow[t]{2}{*}{ fdii } & -0.0166 & $0.0400^{\star \star}$ & -0.00182 & 0.00127 & $0.0297^{\star \star}$ & $-0.0875^{\star}$ \\
\hline & $(0.0132)$ & $(0.0165)$ & $(0.0133)$ & $(0.0117)$ & $(0.0140)$ & $(0.0509)$ \\
\hline \multirow[t]{2}{*}{$h c$} & $-0.0977^{\star}$ & $-1.246^{\star \star}$ & $-1.508^{\star \star \star}$ & $-1.710^{\star \star \star}$ & $-2.069^{\star \star \star}$ & $-1.651^{\star \star \star}$ \\
\hline & $(0.0565)$ & $(0.519)$ & $(0.313)$ & $(0.153)$ & $(0.349)$ & $(0.571)$ \\
\hline \multirow[t]{2}{*}{ water } & $-0.0738^{\star \star \star}$ & -0.0303 & $0.0503^{\star *}$ & & & $-0.115^{\star}$ \\
\hline & $(0.0196)$ & $(0.0309)$ & $(0.0254)$ & & & $(0.0634)$ \\
\hline \multirow[t]{2}{*}{ gini } & & & & & & 0.0207 \\
\hline & & & & & & $(0.0233)$ \\
\hline \multirow[t]{2}{*}{ ores_metal } & & & & & & $0.0982^{\star *}$ \\
\hline & & & & & & $(0.0448)$ \\
\hline Constant & $7.897^{\star \star \star}$ & $10.16^{\star \star \star}$ & 1.343 & $4.977^{\star \star \star}$ & $3.695^{\star \star}$ & $17.24^{\star \star}$ \\
\hline & (2.087) & (2.861) & (2.397) & $(0.792)$ & $(1.696)$ & (6.846) \\
\hline No. of instruments & 74 & 80 & 80 & 80 & 80 & 30 \\
\hline Sargan Test (Prob>chi²) & 0.9406 & 0.6768 & 0.8676 & 0.6925 & 0.1275 & 0.9563 \\
\hline $\begin{array}{l}\text { Arellano-Bond test } \\
\text { (AR2 autocorrelation) }\end{array}$ & 0.8147 & 0.2314 & 0.7585 & 0.6243 & 0.2828 & 0.4327 \\
\hline No. of observations & 811 & 863 & 865 & 878 & 876 & 212 \\
\hline No. of countries & 71 & 74 & 74 & 75 & 75 & 21 \\
\hline
\end{tabular}

Source: Prepared by the authors.

Note: Some specifications are similar, as an attempt was made to check the robustness of the results of the interaction variables. Not all countries report data on all variables. Twenty-four countries report data for the gini variable: Argentina, Armenia, Belarus, Brazil, Colombia, Costa Rica, Dominican Republic, Ecuador, El Salvador, Georgia, Honduras, Kazakhstan, Mexico, Panama, Paraguay, Peru, the Plurinational State of Bolivia, Republic of Moldova, Russian Federation, Serbia, Thailand, Turkey, Ukraine and Uruguay. The following countries are missing for the following variables: sub : Bahamas, Bahrain, Burundi, Democratic Republic of the Congo, Hong Kong (SAR of China), Libya, Papua New Guinea, Qatar, Singapore and Sudan; eci and corceci, Bahamas, Brunei Darussalam, Burundi, Democratic Republic of the Congo, the Gambia, Guinea-Bissau, Guyana, Sierra Leone and Suriname; gdpind, gdpagro, gdpser, corind, coragro and corser, Angola, Bahrain, Kuwait, Liberia and Libya; fdii, Cuba; cre, Cuba and Iran; tech, Angola, Guinea-Bissau, Democratic Republic of the Congo, Liberia and Libya; water, Brunei Darussalam, Hong Kong (SAR) and Libya; hc, Azerbaijan, Bahamas, Belarus, Cuba, Democratic Republic of the Congo, Georgia, Guinea, Guinea-Bissau, Guyana, Lebanon, Libya, Oman, Papua New Guinea and Suriname; ores_metal, Liberia.

Standard error in parentheses ${ }^{\star \star *} p<0.01,{ }^{* \star} p<0.05,{ }^{*} p<0.1$. 
Table 2 shows the effects of corruption control (controlcorrup) and the production structure (eci) on the rate of undernutrition. This parsimonious analysis will help verify the behaviour of these relations without considering the control variables.

Estimation (1) only uses corruption control measured in terms of level. Estimations (2) and (3) use corruption control and (eci) at level, and estimation (3) also considers its lagged effects. Estimation (4) only uses the interaction variable (corceci) between (controlcorrup) and (eci), while estimation (5) controls for the effects of income inequality and non-agricultural commodities.

Estimation (1) shows that increased corruption control reduces the size of the undernourished population. This result is consistent with findings reported in the literature (Blackburn, 2012; Sodré, 2014; Dalberto, 2016), as greater corruption control suggests a lower prevalence of corrupt activities in the country, which in turn improves social development. This result is maintained in estimation (2) and in the lagged estimation (3). At level, estimation (3) finds that greater corruption control is associated with a higher rate of undernutrition. This suggests that lower levels of corruption could be increasing undernutrition, and could be explained by theoretical and empirical literature that exploits arguments and evidence on the benefits of corruption for developing countries (Leff, 1964; Nye, 1967; Huntington, 2002; Li, Xu and Zou, 2000). The results of estimation (3) suggest a non-linear relationship between corruption and development, given the changing direction of the direct effects of corruption control.

In estimations (2) at level and (3) lagged, the isolated effects of the sophistication of the production structure on undernutrition were negative. This suggests that a production structure that is more sophisticated in terms of knowledge, represented by (eci), will generate improvements in the country's social development (Rodrik, 2004; Schteingart, 2015). When considering the interaction variable (corceci), estimation (4) shows that a more sophisticated production structure mitigates the effects of corruption control on undernutrition.

It is arguable that this sophistication of the production structure could be contributing to the effects of corruption as a "lubricant for the wheels", in the sense that less control over corrupt actions would reduce the proportion of the population that is undernourished. This relation can also be interpreted as follows: irrespective of whether the effect of corruption itself on undernutrition is perverse, the more sophisticated production structure enhances that effect, thus reversing the expected relation between corruption control (controlcorrup) and undernutrition.

In control estimation (5), the variables generally maintain the same sign as in the other estimations. The non-agricultural commodities sector was not significant, and income inequality contributed to an increase in undernutrition.

Table 3 reports estimations that include control variables. Estimation (1) uses the control of corruption (controlcorrup), production sophistication (eci) and the interaction variable (corceci), while controlling for FDI, human capital and the proportion of the population with access to improved drinking water sources. The difference between estimations (2) and (3) is that (2) also considers the GDP of the services sector, while (3) considers agricultural GDP. Estimation (4) uses the control of corruption, agricultural GDP, the interaction variable with agricultural GDP, manufacturing industry GDP, FDI and human capital. Estimation (5) considers corruption control, services GDP, the interaction variable with services GDP, industrial GDP, FDI and human capital. Estimation (6) controls for the effects of income inequality and non-agricultural commodities.

In the case of estimations that control for other effects, the lagged dependent variable should also be analysed. The coefficients of these variables had a value of about 0.80 , which may represent the dynamic effect of undernutrition over time. Thus, current undernutrition was persistently influenced by the level of undernutrition in the country in earlier periods. This indicates the difficulty and possible delay in the transition of least developed countries. Given the persistence of the past, this result suggests that the policies implemented will have little immediate impact on undernutrition. 
The effects of corruption control were sensitive to the control variables used: in estimations (2) and (3), which used the interaction of corruption control with manufacturing industry GDP, corruption control had a direct negative impact on undernutrition. In the other estimations, the estimated coefficient was positive. This sensitivity to the effects of corruption control on social development reinforces evidence of a non-linear relationship.

With respect to the interaction variables, when considering the lagged interaction of corruption control with manufacturing industry GDP (corind) in estimations (2) and (3), agriculture (coragro) in estimation (4) and services (corser) in estimation (5), the impact on undernutrition was negative. The results show, therefore, that this case -in which the lagged interaction between more or less sophisticated production structures and corruption control affects social development in the same way - evokes the idea that the country's economic structure will not necessarily mitigate or enhance the past effects of corruption. On the other hand, the result of the lagged variable (corceci) again shows that corruption control increases the rate of undernutrition.

A consideration of interactions in terms of level shows that, in the case of the relatively less sophisticated production structure represented by services GDP in estimation (5), the expected negative effects of corruption control on undernutrition (negative interaction) were strengthened. In other words, greater control of corruption in a less sophisticated structure is associated with less undernutrition. In the more sophisticated structure represented by manufacturing in estimations (2) and (3), the expected negative effects of corruption control on undernutrition were mitigated, generating a positive interaction.

Here again, this idea can be interpreted as follows: since greater control of corruption can be expected to reduce undernutrition and the interaction variable will be positive, it is suggested that the more sophisticated production structure mitigates or reverses the effects of greater corruption control on undernutrition; or even that such a structure strengthens the effects of corruption itself on undernutrition. In this case corruption might help reduce undernutrition. It is then suggested that a more sophisticated production structure distorts the expected effects of corruption control on development, so that the effects of corruption itself and not its control prevail (Shleifer and Vishny, 1993; RoseAckerman, 1997; Mauro, 1997b and 1998), while, under a less sophisticated structure, the effects of controlling corruption dominate.

For the other variables of interest, there were indications that an increase in agricultural GDP (gdpagro) does not necessarily reduce undernutrition (see Rao and Caballero, 1990; Reis, 2012), while manufacturing industry GDP (gdpind) at level had negative effects, but its lagged value suggested a positive effect. This latter relationship is consistent with the literature, since the industrial part of the economy will not necessarily have direct relationships with the social variables. The services share of GDP (gdpser) resulted in an increase in undernutrition. Lastly, economic complexity (eci), when lagged, decreased undernutrition as expected (Hartmann and others, 2015).

With respect to the control variables, for the selected developing countries as a whole, although FDI and water quality may have contributed to reducing undernutrition, this result is specification sensitive. On the other hand, human capital contributed to reducing undernutrition in all estimations.

In the control estimation (6), the variables generally maintain the same sign as in the other estimations. Income inequality was not significant, and the non-agricultural commodities sector contributed to an increase in undernutrition, as non-agricultural resources may not be directly related to social variables, unlike what would happen if only agricultural resources were considered.

In tables 2 and 3, instrument validity tests (Sargan) and autocorrelation tests (Arellano-Bond) showed that the instruments were valid in all estimations and that there was no evidence of autocorrelation. ${ }^{6}$

\footnotetext{
${ }^{6}$ Other control estimations are reported in annex A2. Additional tests were conducted by region and are available from the authors on request.
} 


\section{Corruption, production structure and economic development}

The relation between corruption and the production structure and economic development is illustrated in tables 4 and 5 , which use the logarithm of per capita GDP as dependent variable.

Table 4

Selected developing countries (98): basic dynamic panel model with log GDP per capita as dependent variable, 2002-2014

\begin{tabular}{|c|c|c|c|c|c|}
\hline Variables & (1) & (2) & (3) & (4) & (5) \\
\hline \multirow[t]{2}{*}{$\log d p_{(t-1)}$} & $0.894^{\star \star \star}$ & $1.051^{\star \star \star}$ & $0.822^{\star \star \star}$ & $0.981^{\star \star \star}$ & $0.895^{\star \star \star}$ \\
\hline & $(0.0196)$ & $(0.0246)$ & $(0.0664)$ & $(0.0101)$ & $(0.0332)$ \\
\hline \multirow[t]{2}{*}{ controlcorrup } & $0.350^{\star \star \star}$ & $-0.106^{\star \star}$ & -0.287 & & $0.268^{\star \star \star}$ \\
\hline & $(0.0702)$ & $(0.0470)$ & $(0.184)$ & & $(0.0996)$ \\
\hline \multirow{2}{*}{ controlcorrup $_{(t-1)}$} & & & $0.445^{\star \star}$ & & \\
\hline & & & $(0.174)$ & & \\
\hline \multirow[t]{2}{*}{ eci } & & -0.0304 & 0.0486 & & \\
\hline & & $(0.0188)$ & $(0.0406)$ & & \\
\hline \multirow[t]{2}{*}{$e c i_{(t-1)}$} & & & $0.171^{\star *}$ & & \\
\hline & & & $(0.0683)$ & & \\
\hline \multirow[t]{2}{*}{ corceci } & & & & $0.0643^{\star \star \star}$ & \\
\hline & & & & $(0.0246)$ & \\
\hline \multirow[t]{2}{*}{ gini } & & & & & 0.000841 \\
\hline & & & & & $(0.000635)$ \\
\hline \multirow[t]{2}{*}{ ores_metal } & & & & & $-0.000538^{\star}$ \\
\hline & & & & & $(0.000309)$ \\
\hline \multirow[t]{2}{*}{ Constant } & $0.749^{\star \star \star}$ & $-0.359^{*}$ & $1.505^{\star \star \star}$ & $0.192^{\star \star}$ & $0.801^{\star \star \star}$ \\
\hline & $(0.133)$ & $(0.192)$ & $(0.531)$ & $(0.0850)$ & $(0.236)$ \\
\hline No. of instruments & 92 & 56 & 34 & 85 & 26 \\
\hline Sargan Test (Prob>chi²) & 0.1039 & 0.2427 & 0.5369 & 0.1597 & 0.9875 \\
\hline Arellano-Bond test (AR2 autocorrelation) & 0.4665 & 0.4303 & 0.6330 & 0.4292 & 0.0110 \\
\hline No. of observations & 1174 & 934 & 966 & 905 & 266 \\
\hline No. of countries & 98 & 83 & 85 & 82 & 24 \\
\hline
\end{tabular}

Source: Prepared by the authors.

Note: Some estimations correspond to a smaller number of countries owing to lack of data on the explanatory variables. Twenty-four countries report data for the gini variable: Argentina, Armenia, Belarus, Brazil, Colombia, Costa Rica, Dominican Republic, Ecuador, El Salvador, Georgia, Honduras, Kazakhstan, Mexico, Panama, Paraguay, Peru, the Plurinational State of Bolivia, Republic of Moldova, Russian Federation, Serbia, Thailand, Turkey, Ukraine and Uruguay. The following countries are missing for the following variables: sub: Bahamas, Bahrain, Burundi, Democratic Republic of the Congo, Hong Kong (SAR of China), Libya, Papua New Guinea, Qatar, Singapore and Sudan; eci and corceci, Bahamas, Brunei Darussalam, Burundi, Democratic Republic of the Congo, the Gambia, Guinea-Bissau, Guyana, Sierra Leone and Suriname; gdpind, gdpagro, gdpser, corind, coragro and corser, Angola, Bahrain, Kuwait, Liberia and Libya; fdii, Cuba; cre, Cuba and Iran; tech, Angola, Democratic Republic of the Congo, Guinea-Bissau, Liberia and Libya and; water, Brunei Darussalam, Hong Kong (SAR) and Libya; hc, Azerbaijan, Bahamas, Belarus, Cuba, Democratic Republic of the Congo, Georgia, Guinea, Guinea-Bissau, Guyana, Lebanon, Libya, Oman, Papua New Guinea and Suriname; ores_metal, Liberia. Standard error in parentheses ${ }^{\star \star \star} p<0.01,{ }^{\star \star} p<0.05,{ }^{\star} p<0.1$.

Table 4 shows the effects of corruption control and the production structure on per capita GDP. Estimation (1) only uses corruption control at level. Estimations (2) and (3) use corruption control and (eci) at level; and estimation (3) also considers its lagged effects. estimation (4) only uses the interaction variable (corceci). Estimation (5) controls for the effects of income inequality and non-agricultural commodities.

Estimations (1) and (3) show that greater control of corruption increases per capita output, which is in line with findings reported in the literature (Mauro, 1995 and 1997a; Akçay, 2006). In estimation (2), however, the negative coefficient is consistent with theoretical and empirical literature on the benefits of 
corruption for developing countries (Klitgaard, 1994; Acemoglu and Verdier, 1998). Again, the shift in the direction of the direct effects of corruption control on development suggests a non-linear relationship. The lagged coefficient of (eci) was positive.

When considering the interaction variable (corceci), estimation (4) shows that a more sophisticated production structure enhances the effects of corruption control. This may indicate that corruption can have a harmful effect on per capita output, hence the importance of greater corruption control within a more sophisticated production structure. While the expected positive effects of corruption control on output are enhanced, the effects of corruption itself (which is expected to be negative for production) can be mitigated. The mitigation of corruption within a more sophisticated production structure may indicate that production-structure sophistication and corrupt behaviour are actually not related.

In the control estimation (5), the variables generally maintain the same sign as in the other estimations. The Gini coefficient was non-significant, and non-agricultural commodities had a negative impact on per capita GDP, contrary to expectations but in line with the results reported by Sachs and Warner (2001).

Some additional control variables are considered in table 5. Estimation (1) uses control of corruption (controlcorrup), production sophistication (eci), the interaction variable (corceci), FDI, human capital and the proportion of the population using improved drinking water sources. The difference between estimates (2) and (3) is that agricultural GDP is also considered in the former. Estimation (4) uses control of corruption, agricultural GDP, manufacturing GDP, the interaction variable with agricultural GDP, FDI, human capital and trade openness. The difference between estimations (5) and (6) is that the former also considers manufacturing GDP. Estimation (7) controls for the effects of income inequality and non-agricultural commodities.

The coefficients of the lagged dependent variable were positive around 0.85 and represent the dynamic effect of per capita GDP. The persistence of past effects on current per capita GDP suggests that it is hard for GDP levels to change significantly and for economies to rapidly attain a higher level of development. Consequently, efficient economic policies are needed to improve this situation over time.

The effects of corruption control, both at level and when lagged, were again very sensitive to the control variables used, which may indicate a non-linear relationship between corruption and development.

With respect to the interaction variables, the at-level coefficients of the interaction between corruption and agricultural and services GDP in estimations (4), (5) and (6), which represent a relatively less sophisticated production structure, change sign relative to their lagged values in estimations (4) and (6). In level terms, the expected positive effects of corruption control on per capita GDP are enhanced in a less sophisticated production structure. In other words, when production is less sophisticated, corruption is easier to control, so that the effects of corruption (possibly negative on output) are mitigated and this leads to an increase in per capita GDP. In this case, corruption might have negative effects on economic development, since its control generates an improvement in per capita GDP. Moreover, in a less sophisticated production structure, the effects of corruption control could outweigh the effects of corruption itself. 
Table 5

Selected developing countries (98): dynamic panel with the logarithm of per capita GDP as dependent variable, 2002-2014

\begin{tabular}{|c|c|c|c|c|c|c|c|}
\hline Variables & (1) & (2) & (3) & (4) & (5) & (6) & (7) \\
\hline \multirow[t]{2}{*}{$\operatorname{loggdp}_{(t-1)}$} & $0.748^{\star \star \star}$ & $0.892^{\star \star \star}$ & $0.861^{* \star \star}$ & $0.921^{\star \star \star}$ & $0.826^{\star \star \star}$ & $0.859^{\star \star \star}$ & $0.920^{\star \star \star}$ \\
\hline & $(0.0544)$ & $(0.0364)$ & $(0.0575)$ & $(0.0325)$ & $(0.0605)$ & $(0.0636)$ & $(0.0710)$ \\
\hline \multirow[t]{2}{*}{ controlcorrup } & $0.235^{\star \star \star}$ & 0.206 & 0.301 & -0.205 & $-0.692^{\star \star}$ & $-1.177^{*}$ & 2.099 \\
\hline & $(0.0644)$ & $(0.205)$ & $(0.259)$ & $(0.127)$ & $(0.340)$ & $(0.603)$ & $(1.374)$ \\
\hline \multirow[t]{2}{*}{ controlcorrup $_{(t-1)}$} & & $-0.422^{\star *}$ & $-0.702^{\star \star}$ & $0.274^{\star \star}$ & & $0.960^{*}$ & $1.922^{*}$ \\
\hline & & $(0.211)$ & $(0.282)$ & $(0.134)$ & & $(0.554)$ & $(1.158)$ \\
\hline \multirow[t]{2}{*}{ corceci } & -0.0921 & & & & & & \\
\hline & $(0.0883)$ & & & & & & \\
\hline \multirow[t]{2}{*}{ corind } & & -0.00847 & -0.00678 & & & & $-0.0705^{\star}$ \\
\hline & & $(0.00720)$ & $(0.00887)$ & & & & $(0.0428)$ \\
\hline \multirow{2}{*}{$\operatorname{corind}_{(t-1)}$} & & $0.0199^{\star \star \star}$ & $0.0291^{\star \star \star}$ & & & & -0.0518 \\
\hline & & $(0.00764)$ & $(0.0102)$ & & & & $(0.0340)$ \\
\hline \multirow[t]{2}{*}{ coragro } & & & & $0.0103^{*}$ & & & \\
\hline & & & & $(0.00564)$ & & & \\
\hline \multirow[t]{2}{*}{ coragro $_{(t-1)}$} & & & & $-0.00896^{\star}$ & & & \\
\hline & & & & $(0.00488)$ & & & \\
\hline \multirow[t]{2}{*}{ corser } & & & & & $0.0174^{\star \star *}$ & $0.0219^{* *}$ & \\
\hline & & & & & $(0.00626)$ & $(0.0109)$ & \\
\hline \multirow[t]{2}{*}{$\operatorname{corser}_{(t-1)}$} & & & & & & $-0.0179^{*}$ & \\
\hline & & & & & & $(0.0105)$ & \\
\hline \multirow[t]{2}{*}{ eci } & 0.0376 & & & & & & \\
\hline & $(0.0342)$ & & & & & & \\
\hline \multirow[t]{2}{*}{ gdpind } & & $0.0151^{\star \star \star}$ & $0.0154^{\star \star \star}$ & $0.0120^{\star \star \star}$ & -0.00353 & & $0.049^{* \star *}$ \\
\hline & & $(0.00294)$ & $(0.00348)$ & $(0.00124)$ & $(0.00323)$ & & $(0.0163)$ \\
\hline \multirow{2}{*}{ gdpind $_{(t-1)}$} & & $-0.0179^{\star \star \star}$ & $-0.0195^{\star \star \star}$ & $-0.0105^{\star * \star}$ & & & -0.00684 \\
\hline & & $(0.00318)$ & $(0.00428)$ & $(0.00137)$ & & & $(0.0127)$ \\
\hline \multirow{2}{*}{ gdpagro } & & -0.000506 & & $-0.00395^{\star}$ & & & $0.019^{\star \star \star}$ \\
\hline & & $(0.00241)$ & & $(0.00222)$ & & & $(0.0075)$ \\
\hline \multirow{2}{*}{$\operatorname{gdpagro}_{(t-1)}$} & & $-0.00519^{\star \star}$ & & & & & $-0.03^{\star \star \star}$ \\
\hline & & $(0.00211)$ & & & & & $(0.0069)$ \\
\hline \multirow[t]{2}{*}{ gdpser } & & & & & $-0.0184^{\star \star \star}$ & $-0.0194^{\star \star \star}$ & \\
\hline & & & & & $(0.00418)$ & $(0.00430)$ & \\
\hline \multirow[t]{2}{*}{$\operatorname{gdpser}_{(t-1)}$} & & & & & $0.00644^{\star \star \star}$ & $0.0172^{\star \star \star}$ & \\
\hline & & & & & (0.00135) & $(0.00446)$ & \\
\hline \multirow[t]{2}{*}{ fdii } & $0.00628^{\star \star \star}$ & & & 0.000544 & 0.00194 & -0.000268 & \\
\hline & $(0.00159)$ & & & $(0.000334)$ & $(0.00138)$ & $(0.00216)$ & \\
\hline$h c$ & $0.149^{\star \star \star}$ & $0.0822^{\star \star \star}$ & $0.187^{\star \star}$ & $0.0642^{\star \star \star}$ & $0.331^{\star \star \star}$ & $0.241^{\star \star}$ & $0.265^{*}$ \\
\hline & $(0.0339)$ & $(0.0232)$ & $(0.0765)$ & $(0.0201)$ & $(0.0811)$ & $(0.104)$ & $(0.136)$ \\
\hline water & $0.0101^{\star * \star}$ & & & & & & \\
\hline & $(0.00222)$ & & & & & & \\
\hline abecom & & & & 0.000135 & & & \\
\hline & & & & (9.13e-05) & & & \\
\hline gini & & & & & & & 0.00451 \\
\hline & & & & & & & $(0.0049)$ \\
\hline ores_metal & & & & & & & -0.00540 \\
\hline & & & & & & & $(0.0044)$ \\
\hline Constant & $0.764^{\star \star \star}$ & $0.824^{\star \star \star}$ & $0.730^{\star \star \star}$ & $0.484^{\star \star}$ & $1.303^{\star \star \star}$ & $0.724^{*}$ & $-1.512^{\star \star}$ \\
\hline & $(0.159)$ & $(0.284)$ & $(0.255)$ & $(0.199)$ & $(0.265)$ & $(0.374)$ & $(0.714)$ \\
\hline No. of instruments & 77 & 81 & 52 & 84 & 65 & 45 & 27 \\
\hline Sargan Test (Prob>chi²) & 0.1976 & 0.7973 & 0.3435 & 0.5232 & 0.2300 & 0.8234 & 0.2546 \\
\hline $\begin{array}{l}\text { Arellano-Bond test } \\
\text { (AR2 autocorrelation) }\end{array}$ & 0.1752 & 0.1038 & 0.0917 & 0.936 & 0.1181 & 0.2665 & 0.9824 \\
\hline No. of observations & 873 & 950 & 950 & 937 & 947 & 947 & 237 \\
\hline No. of countries & 83 & 81 & 81 & 81 & 81 & 81 & 22 \\
\hline
\end{tabular}

Source: Prepared by the authors.

Note: Some specifications are similar, as an attempt was made to verify the robustness of the results of the interaction variables. Twenty-four countries report data for the gini variable: Argentina, Armenia, Belarus, Brazil, Colombia, Costa Rica, Dominican Republic, Ecuador, El Salvador, Georgia, Honduras, Kazakhstan, Mexico, Panama, Paraguay, Peru, the Plurinational State of Bolivia, Republic of Moldova, Russian Federation, Serbia, Thailand, Turkey, Ukraine and Uruguay. The following countries are missing for the following variables: sub: Bahamas, Bahrain, Burundi, Democratic Republic of the Congo, Hong Kong (SAR of China), Libya, Papua New Guinea, Qatar, Singapore and Sudan; eci and corceci, Bahamas, Brunei Darussalam, Burundi, Democratic Republic of the Congo, the Gambia, Guinea-Bissau, Guyana, Sierra Leone and Suriname; gdpind, gdpagro, gdpser, corind, coragro and corser, Angola, Bahrain, Kuwait, Liberia and Libya; fdii, Cuba; cre, Cuba and Iran; tech, Angola, Democratic Republic of the Congo Guinea-Bissau, Liberia and Libya; water, Brunei Darussalam, Hong Kong (SAR) and Libya; hc, Azerbaijan, Bahamas, Belarus, Cuba, Democratic Republic of the Congo, Georgia, Guinea, Guinea-Bissau, Guyana, Lebanon, Libya, Oman, Papua New Guinea and Suriname; ores_metal, Liberia. Standard error in parentheses ${ }^{\star \star \star} p<0.01,{ }^{* \star} p<0.05,{ }^{\star} p<0.1$. 
When the lagged values were used, the effects of the interaction variables changed. This suggests that, even when lagged, corruption can have different effects on economic development depending on the sophistication of the country's production structure. When considering the interaction in lagged-value terms with agricultural GDP and services GDP, which have lower levels of sophistication in their production structure than the industrial sector, the effects of corruption control (which is expected to improve per capita GDP values) are actually mitigated or reversed owing to the low production sophistication. Conversely, when considering the interaction with manufacturing industry GDP in estimations (2) and (3), the effects of corruption control are enhanced because production is more sophisticated. In other words, despite the fact that different lagged production structures affect per capita GDP differently, these effects do not support the interpretation that a more sophisticated production structure strengthens the effects of corruption by distorting the effects of corruption control on corrupt behaviour, as the results in tables 2 and 3 and the values in table 5 suggest. Thus, the "lubrication of the wheels" argument for the effect of corruption on economic development, in this case using the lagged variables, would be associated with a less sophisticated production structure.

Among the other variables of interest, agricultural GDP affected per capita GDP adversely both at level and when lagged, as also suggested by some studies in the literature (Sachs and Warner, 2001). This could be seen as the effect of agriculture being greater in social than in economic terms, which would be more strongly influenced by manufacturing. While manufacturing GDP at level increased per capita GDP, its lagged value had a negative impact. On the other hand, while services GDP decreased per capita GDP, possibly for the same reason as the agriculture sector, its lagged values improved current per capita GDP.

Turning to the control variables, FDI and improved drinking water sources both increased per capita GDP in estimation (1); and human capital had the same effect in all of the estimations.

In control estimation (7), the variables generally have the same sign as in the other estimations. The interaction variable (corind) at level had a negative impact on per capita GDP, thus corroborating the hypothesis that the expected effects of corruption control cold be distorted in a relatively more sophisticated production structure. The Gini coefficient and non-agricultural commodities were non-significant.

In Tables 4 and 5, the Sargan instrument validity tests indicated that the instruments were valid in all estimations; ${ }^{7}$ and the Arellano-Bond tests for autocorrelation proved negative, except for estimations (5) in table 4 and (3) in table 5.

\section{Non-linear analysis}

While common sense suggests that corruption should affect a country's economy adversely, as documented in Mauro (1997a), its effects are controversial both in theory and also in empirical studies. Authors who discuss the benefits of corruption include Leff (1964), Nye (1967), Huntington (2002), Klitgaard (1994), Bardhan (1997) and Acemoglu and Verdier (1998).

The effects of corruption and the production structure on countries' development suggest a two-way causality, and exploring this aspect could help deepen the analysis. The effects of corruption control would be reversed, as the existence of corruption could boost per capita GDP, for example, and reduce undernutrition by stimulating investments in infrastructure and physical capital. Thus, if corruption exists, people would be willing to choose more advanced technologies or investment projects in more sophisticated sectors, in order to embezzle funds. In other words, corruption would stimulate certain types of investment, which would promote development. Thus, by interacting with the sophistication of the production structure, the development effects of increased corruption control would be reversed.

Considering the results obtained for the lagged variables in table 5 , a more sophisticated production structure seems to mitigate the effects of corruption by enhancing the benefits of controlling it. This

\footnotetext{
7 Other control estimations are reported in annex A3. Additional tests may be obtained from the authors on request.
} 
result is consistent with the findings reported by Ruhashyankiko and Yehoue (2006). The literature also suggests that embezzlement produces inefficient development outcomes, as argued by Rose-Ackerman (1997) and Mauro (1997b and 1998).

The broad scope of this topic can be understood from the observation made by Hausmann and others (2011) on relations with the sophisticated production structure. Despite suggesting a positive relation between the economic complexity index and per capita GDP, as shown in figure 1, those authors explain that two countries with similar per capita incomes may have different levels of economic complexity. An example is provided by China and Peru; while China's per capita GDP was US\$ 6,032.62 in 2014 and Peru's was very similar at US\$ 5,861.41 (World Bank, $\mathrm{n} / \mathrm{da}$ ), in constant 2010 values), their economic complexity indices were 0.74 and -0.43 , respectively. While the authors use this index, the argument is also valid when using sectoral GDP to represent the production structure.

The aim is therefore to understand why the direct effects of corruption control on development are so sensitive to different specifications. One possible reason is that the effect of corruption may depend on other factors that are specific to each country. Thus, corruption is expected to be non-linear and its effects $U$-shaped.

The quadratic function of corruption control was estimated according to the specification represented by equation (3). ${ }^{8}$

$$
\begin{aligned}
& \operatorname{sub}_{t}=5.0271+0.8788 \mathrm{sub}_{t-1}-6.9247 \text { corcon }_{t}+9.2571 \text { corcon }_{t}^{2}-0.0191 \text { fdii }_{t}-1.0149 \mathrm{hc}_{t} \\
& (0.8436)^{* * *}(0.0165)^{* * *} \quad(1.1867)^{* * *} \quad(1.4777)^{* * *} \quad(0.0103)^{*} \quad(0.1701)^{* * *}
\end{aligned}
$$

Differentiating with respect to the control of observed corruption reveals that corruption control has a point of inflexion at a value of 0.374 . Figure 2 illustrates the quadratic relationship between corruption control and development (simulations of values on a scale of 0 to 10 for undernutrition).

Figure 2

Impact of corruption control on development

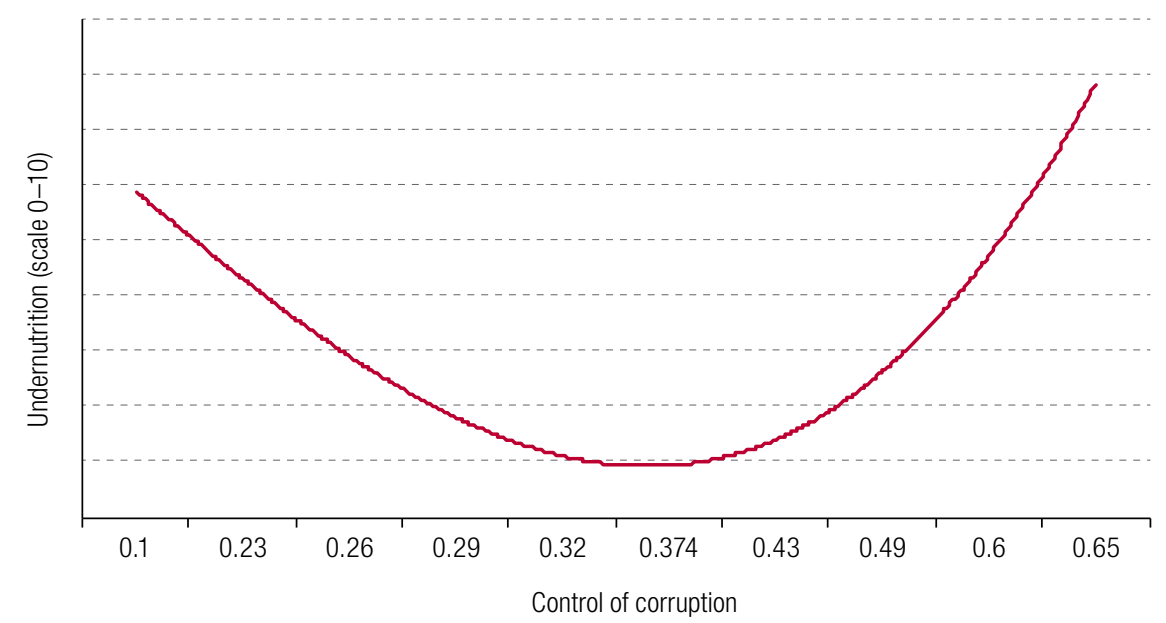

Source: Prepared by the authors.

Figure 2 shows that, as corruption control intensifies, undernutrition decreases; but, as from the point of inflexion, further control of corruption increases undernutrition. This is consistent with the findings reported in Houston (2007), Sobral (2014) and Swaleheen (2011), the latter of which justifies this result with the argument of "lubricating the wheels of economic growth".

\footnotetext{
8 Standard error in parentheses. The estimated coefficients are statistically significant at ${ }^{* *} \mathrm{p}<0.01$ and ${ }^{*} \mathrm{p}<0.1$. Number of instruments: 80. Sargan test (Prob>chi2): 0.5827. Arellano-Bond test (AR2 autocorrelation): 0.8578. Number of observations: 934. Number of countries:78.
} 
A review of the corruption control data used, relating to 2014 , shows that $61 \%$ of the 98 countries in the sample have a level of corruption control of up to 0.33 , while the remaining $39 \%$ have a level of 0.42 or more. This means that, in this context, most of the countries in the sample could benefit from greater corruption control.

The joint analysis of development, production structure and corruption in an applied model has made it possible to verify the non-linear behaviour of the relationship, and to observe how the development effects of corruption are produced through the sophistication of the production structure, thereby contributing to the existing literature on the subject in general.

\section{Concluding remarks}

The development literature is very wide-ranging. Corruption and the sophistication of the country's production structure are two aspects analysed as determinants of development. Despite the growing literature on the subject, gaps remain, particularly with regard to the joint effects of aspects of corruption and the sophistication of the production structure. This makes it important to analyse the interaction between variables known to affect development in order to observe the intensity of their effects.

The aim of this study was to examine how the production structure, corruption and the possible effects of interaction between these two variables influence the socioeconomic development of developing countries.

While it was found that corruption can have either positive or negative impacts on a country's development, there are signs of consensus on its negative influence. It was also noted that corruption can be enhanced in environments involving a higher level of technology, because more advanced technologies used in the process and structure of production can facilitate the misappropriation of funds.

The study has sought to explore the effects of corruption on development in two areas: in the first place, development is represented by the percentage of the population who are undernourished, while in the second, the development variable is represented by per capita GDP. Although the two estimations differ in terms of the direct development effects of sophistication of the production structure, they suggest that a more sophisticated production structure tends to strengthen the development effects of corruption itself, when this variable interacts with corruption control. This finding is important when economic policies are formulated to promote national development.

As for the direct effects of corruption control, the parameters were not stable with respect to changes in specification. The sensitivity of the results in relation to socioeconomic development was interpreted as a sign of non-linear behaviour and should therefore be treated with care when anti-corruption policies are in place. In the case of the control variables, human capital was shown to be positive for socioeconomic development in different estimations. The foreign investment and drinking water variables were sensitive to specification.

The contribution made by this study has been to analyse the simultaneous effects of these indicators, broadening the discussion on the subject. In addition, the variables selected made it possible to highlight the effects of corruption and the production structure, both from the point of view of economic development and from the social development standpoint.

The development effects of corruption control under different production structures and the non-linearity of the effects of corruption itself highlight the need to consider both aspects when implementing public policies, whether targeted on the sophistication of the production structure or on anti-corruption policies. 


\section{Bibliography}

Acemoglu, D. and T. Verdier (1998), "Property rights, corruption and the allocation of talent: a general equilibrium approach", The Economic Journal, vol. 108, No. 450, Hoboken, Wiley.

Aidt, T., J. Dutta and V. Sena (2008), "Governance regimes, corruption and growth: theory and evidence", Journal of Comparative Economics, vol. 36, No. 2, Amsterdam, Elsevier.

Akçay, S. (2006), "Corruption and human development", Cato Journal, vol. 26, No. 1, Washington, D.C., Cato Institute.

Arellano, M. and S. Bond (1991), "Some tests of specification for panel data: Monte Carlo evidence and an application to employment equations", Review of Economic Studies, vol. 58, No. 2, Oxford, Oxford University Press.

Arellano, M. and O. Bover (1995), "Another look at the instrumental variable estimation of error-components models", Journal of Econometrics, vol. 68, No. 1, Amsterdam, Elsevier.

Baltagi, B. H. (2005), Econometric Analysis of Panel Data, Chichester, John Wiley \& Sons.

Bardhan, P. (1997), "Corruption and development: a review of issues", Journal of Economic Literature, vol. 35, No. 3, Nashville, American Economic Association.

Blackburn, K. (2012), "Corruption and development: explaining the evidence", The Manchester School, vol. 80, No. 4, Hoboken, Wiley.

Blundell, R. and S. Bond (1998), "Initial conditions and moment restrictions in dynamic panel data models", Journal of Econometrics, vol. 87, No. 1, Amsterdam, Elsevier.

Dalberto, C. R. (2016), "Corrupção, finanças políticas e liberdades econômicas: uma abordagem de dados em painel", paper presented at the Nineteenth Economy Meeting of the South Region (ANPEC Sul), Florianopolis, Brazilian Association of Graduate Programs in Economics (ANPEC) [online] https://www. anpec.org.br/sul/2016/submissao/files_l/i2-2c6ca123dd97082342dbfd8d08e1befc.pdf.

FAO (Food and Agriculture Organization of the United Nations) (2016), "Food security indicators" [online] http://www.fao.org/economic/ess/ess-fs/ess-fadata/en/\#.WKBDXW8rLIU.

Feenstra, R. C., R. Inklaar and M. P. Timmer (2015), "The next generation of the Penn World Table", American Economic Review, vol. 105, No. 10, Nashville, American Economic Association.

Hartmann, D. and others (2015), "Linking economic complexity, institutions and income inequality", Cornell University Library, Ithaca [online] https://arxiv.org/vc/arxiv/papers/1505/1505.07907v3.pdf.

Hausmann, R. and others (2011), The Atlas of Economic Complexity: Mapping Paths to Prosperity, New Hampshire, Puritan Press [online] http://atlas.media.mit.edu/static/pdf/atlas/AtlasOfEconomicComplexity.pdf.

Hines, J. R. (1995), "Forbidden payment: foreign bribery and American business after 1977", NBER Working Paper, No. w5266, 1995.

Houston, D. A. (2007), "Can corruption ever improve an economy?", Cato Journal, vol. 27, No. 3, Washington, D.C., Cato Institute.

Huntington, S. P. (2002), "Modernization and corruption", Political Corruption: concepts and contexts, A. J. Heidenheimer and M. Johnston (ed.), New Jersey, Transaction Publishers.

Kaufmann, D., A. Kraay and M. Mastruzzi (2010), "The worldwide governance indicators: methodology and analytical issues", World Bank Policy Research Working Paper, No. 5430, Washington, D.C., World Bank.

Klitgaard, R. E. (1994), A corrupção sob controle, Rio de Janeiro, Jorge Zahar.

Leff, N. H. (1964), "Economic development through bureaucratic corruption", American Behavioral Scientist, vol. 8, No. 3, Thousand Oaks, Sage.

Leite, C. and J. Weidmann (1999), "Does mother nature corrupt? Natural resources, corruption, and economic growth", IMF Working Paper, No. WP/99/85, Washington, D.C., International Monetary Fund (IMF).

Li, H., L. C. Xu and H. Zou (2000), "Corruption, income distribution, and growth", Economics \& Politics, vol. 12, No. 2, Hoboken, Wiley.

Mahdavi, P. (2014), "Extortion in the oil states: nationalization, regulatory structure, and corruption", Political Science Department Working Paper, Los Angeles, University of California [online] https://pdfs.semanticscholar. org/cf99/d839edac4d64e576553799fab2194798f798.pdf.

Mauro, P. (1998), "Corruption and the composition of government expenditure", Journal of Public Economics, No. 69, Amsterdam Elsevier.

(1997a), "The effects of corruption on growth, investment, and government expenditure: a cross-country analysis", Corruption and the Global Economy, K. A. Elliot (ed.), Washington, D.C., Peterson Institute for International Economics.

(1997b), "Why worry about corruption?", Economic Issues, No. 6, Washington, D.C., International Monetary Fund. 
(1995), "Corruption and growth", The Quarterly Journal of Economics, vol. 110, No. 3, Oxford, Oxford University Press.

Nye, J. S. (1967), "Corruption and political development: a cost-benefit analysis", The American Political Science Review, vol. 61, No. 2, Washington, D.C., American Political Science Association.

OEC (The Observatory of Economic Complexity) (n/da), "Economic complexity rankings", Cambridge, Massachusetts Institute of Technology (MIT) [online] https://oec.world/en/rankings/country/eci/.

(n/db), "How does complexity compare to GDP per capita? (2014)", Cambridge, Massachusetts Institute of Technology (MIT) [online] http://atlas.media.mit.edu/en/visualize/scatter/hs07/gdp_pc_constant/show/ all/all/2014.

(n/dc), "What is economic complexity?", Cambridge, Massachusetts Institute of Technology (MIT) [online] http://atlas.media.mit.edu/en/resources/economic_complexity.

OECD (Organization for Economic Cooperation and Development) (2013), Issues Paper on Corruption and Economic Growth [online] http://www.oecd.org/g20/topics/anti-corruption/issues-paper-on-corruptionand-economic-growth.htm.

Rao, J. M. and J. M. Caballero (1990), "Agricultural performance and development strategy: retrospect and prospect", World Development, vol. 18, No. 6, Amsterdam, Elsevier.

Reis, C. F. de B. (2012), "Estrutura produtiva e instituições no desenvolvimento econômico a partir de recursos naturais: uma análise teórica e crítica", Anais do XL Encontro Nacional de Economia, Porto de Galinhas, Pernambuco, Brazilian Association of Graduate Programs in Economics (ANPEC) [online] https://www. anpec.org.br/encontro/2012/inscricao/files_l/i5-56cda81f3ee955d6769594f3830964cd.pdf.

Rock, M. T. and H. Bonnett (2004), "The comparative politics of corruption: accounting for the east Asian paradox in empirical studies of corruption, growth and investment", World Development, vol. 32, No. 6, Amsterdam, Elsevier.

Rodrik, D. (2004), "Industrial policy for the twenty-first century" [online] https://www.sss.ias.edu/files/pdfs/ Rodrik/Research/industrial-policy-twenty-first-century.pdf.

Rose-Ackerman, S. (1997), "The political economy of corruption", Corruption and the Global Economy, K. A. Elliott (ed.), Washington, D.C., Peterson Institute for International Economics.

Ruhashyankiko, J. F. and E. B. Yehoue (2006), "Corruption and technology-induced private sector development", IMF Working Paper, No. 06/198, Washington, D.C., International Monetary Fund (IMF).

Sachs, J. D. and A. M. Warner (2001), "The curse of natural resources", European Economic Review, vol. 45, No. 4-6, Amsterdam, Elsevier.

Schteingart, D. (2015), "Production structure, composition of exports, technological capabilities and economic development: does what countries export absolutely matter?", paper presented at the Thirteenth Globelics International Conference, Havana, 23-25 September.

Shleifer, A. and R. W. Vishny (1993), "Corruption", The Quarterly Journal of Economics, vol. 108, No. 3, Oxford, Oxford University Press.

Sobral, E. F. M. (2014), "Corrupção e os seus efeitos sobre a dinâmica do crescimento econômico regional: uma análise do caso brasileiro", master thesis, Recife, Federal University of Pernambuco.

Sodré, F. R. A. (2014), "Os impactos da corrupção no desenvolvimento humano, desigualdade de renda e pobreza dos municípios brasileiros", master thesis, Recife, Federal University of Pernambuco.

Swaleheen, M. (2011), "Economic growth with endogenous corruption: an empirical study", Public Choice, vol. 146, No. 1-2, Berlin, Springer.

United Nations (n/da), "Millennium Development Goals Indicators" [online] http://mdgs.un.org/unsd/mdg/ Data.aspx.

_ (n/db), "Millennium Development Goals Indicators. Goal 1: eradicate extreme poverty and hunger" [online] http://mdgs.un.org/unsd/mdg/Metadata.aspx?Indicatorld=0\&Seriesld=566.

WITS (World Integrated Trade Solution) (2018), "Product group" [online] https://wits.worldbank.org/CountryProfile/ en/Country/BY-COUNTRY/StartYear/2002/EndYear/2014/TradeFlow/Export/Indicator/XPRT-PRDCT-SHR/ Partner/WLD/Product/OresMtls.

World Bank (n/da), "World Bank open data" [online] http://data.worldbank.org. (n/db), "Worldwide Governance Indicators. International country risk guide" [online] info.worldbank.org/ governance/wgi/pdf/PRS.xlsx.

(n/dc), "Worldwide Governance Indicators. WGl aggregation methodology" [online] http://info.worldbank. org/governance/wgi/Home/Documents\#wgiAggMethodology.

World Economic Forum (2012), "Global Agenda Councils. Anti-corruption" [online] http://reports.weforum. org/global-agenda-council-2012/councils/anti-corruption. 


\section{Annex A1}

Table A1.1

List of countries

\begin{tabular}{lll}
\hline Albania & Ghana & Panama \\
Algeria & Guatemala & Papua New Guinea \\
Angola & Guinea & Paraguay \\
Argentina & Guinea-Bissau & Peru \\
Armenia & Guyana & Philippines \\
Azerbaijan & Honduras & Qatar \\
Bahamas & Hong Kong (Special Administrative Region of China) & Republic of Korea \\
Bahrain & India & Republic of Moldova \\
Bangladesh & Indonesia & Russian Federation \\
Belarus & Iran & Saudi Arabia \\
Bolivia (Plurinational State of) & Jamaica & Senegal \\
Botswana & Jordan & Serbia \\
Brazil & Kazakhstan & Sierra Leone \\
Brunei Darussalam & Kenya & Singapore \\
Burkina Faso & Kuwait & South Africa \\
Burundi & Lebanon & Sri Lanka \\
Cameroon & Liberia & Sudan \\
Chile & Libya & Suriname \\
China & Madagascar & Thailand \\
Colombia & Malawi & Togo \\
Congo (Republic of) & Malaysia & Trinidad and Tobago \\
Costa Rica & Mali & Tunisia \\
Côte d'lvoire & Mexico & Turkey \\
Cuba & Mongolia & Ukraine \\
Democratic Republic of the Congo & Morocco & Uganda \\
Dominican Republic & Mozambique & United Arab Emirates \\
Ecuador & Namibia & United Republic of Tanzania \\
Egypt & Nicaragua & Uruguay \\
El Salvador & Niger & Venezuela (Bolivarian Republic of) \\
Ethiopia & Nigeria & Viet Nam \\
Gabon & Oman & Yemen \\
Gambia & Pakistan & Zambia \\
Georgia & & Zimbabwe \\
\hline & & \\
Source: & &
\end{tabular}

Source: Prepared by the authors.

Note: Estimations made with the variable sub do not include the following countries: Bahamas, Bahrain, Burundi, Democratic Republic of the Congo, Hong Kong (SAR), Libya, Papua New Guinea, Qatar, Singapore and Sudan. 


\section{Annex A2}

Table A2.1

Control estimations, undernutrition as dependent variable, 2002-2014

\begin{tabular}{|c|c|c|c|c|}
\hline \multirow{2}{*}{ Variables } & \multicolumn{2}{|c|}{ Partial } & \multicolumn{2}{|c|}{ Complete } \\
\hline & (B1) & (B2) & (B1) & (B2) \\
\hline \multirow{2}{*}{$\operatorname{sub}_{(t-1)}$} & $0.819^{\star \star \star}$ & $0.848^{\star \star \star}$ & $0.712^{\star \star \star}$ & $0.756^{\star \star \star}$ \\
\hline & $(0.0595)$ & $(0.0605)$ & $(0.0849)$ & $(0.0758)$ \\
\hline \multirow[t]{2}{*}{ controlcorrup } & $-3.238^{* \star *}$ & $-2.478^{*}$ & $-5.715^{\star \star \star}$ & 2.853 \\
\hline & $(1.155)$ & $(1.485)$ & $(2.094)$ & $(28.61)$ \\
\hline \multirow{2}{*}{ controlcorrup $_{(t-1)}$} & & 1.541 & & \\
\hline & & $(1.680)$ & & \\
\hline \multirow[t]{2}{*}{ coragro } & & & $0.328^{*}$ & \\
\hline & & & $(0.184)$ & \\
\hline \multirow[t]{2}{*}{ coragro $_{(t-1)}$} & & & -0.0154 & \\
\hline & & & $(0.163)$ & \\
\hline \multirow[t]{2}{*}{ corser } & & & & -0.0638 \\
\hline & & & & $(0.500)$ \\
\hline \multirow[t]{2}{*}{$\operatorname{corser}_{(t-1)}$} & & & & $-0.0784^{*}$ \\
\hline & & & & $(0.0440)$ \\
\hline \multirow[t]{2}{*}{ eci } & & $-0.623^{\star \star}$ & & \\
\hline & & $(0.245)$ & & \\
\hline \multirow[t]{2}{*}{$e c i_{(t-1)}$} & & 0.0392 & & \\
\hline & & $(0.307)$ & & \\
\hline \multirow[t]{2}{*}{ gdpind } & & & 0.0434 & $0.138^{*}$ \\
\hline & & & $(0.0617)$ & $(0.0829)$ \\
\hline \multirow[t]{2}{*}{$\operatorname{gdpind}_{(t-1)}$} & & & -0.0297 & -0.0568 \\
\hline & & & $(0.0662)$ & $(0.0756)$ \\
\hline \multirow[t]{2}{*}{ gdpser } & & & & 0.117 \\
\hline & & & & $(0.147)$ \\
\hline \multirow[t]{2}{*}{ fdii } & & & $-0.0842^{*}$ & -0.103 \\
\hline & & & $(0.0510)$ & $(0.0655)$ \\
\hline \multirow[t]{2}{*}{ hc } & & & $-4.740^{\star \star \star}$ & $-4.592^{\star \star *}$ \\
\hline & & & $(1.475)$ & (1.538) \\
\hline \multirow[t]{2}{*}{ gini } & $0.200^{\star \star \star}$ & 0.0169 & -0.0191 & -0.0461 \\
\hline & $(0.0566)$ & $(0.0184)$ & $(0.0349)$ & $(0.0416)$ \\
\hline \multirow[t]{2}{*}{ ores_metal } & $0.0206^{* *}$ & $-0.0121^{\star \star \star}$ & $0.0499^{\star \star \star}$ & $0.0490^{\star *}$ \\
\hline & $(0.00865)$ & $(0.00416)$ & $(0.0176)$ & $(0.0192)$ \\
\hline \multirow[t]{2}{*}{ Constant } & $-6.173^{\star \star \star}$ & $0.904^{\star \star}$ & $16.56^{\star \star \star}$ & 9.029 \\
\hline & $(2.047)$ & $(0.437)$ & $(5.608)$ & (7.388) \\
\hline No. of instruments & 33 & 17 & 31 & 21 \\
\hline Sargan Test (Prob>chi²) & 0.6692 & 0.5307 & 0.9903 & 0.8736 \\
\hline Arellano-Bond test (AR2 autocorrelation) & 0.1925 & 0.1928 & 0.5678 & 0.3358 \\
\hline No. of observations & 266 & 236 & 223 & 223 \\
\hline No. of countries & 24 & 23 & 22 & 22 \\
\hline
\end{tabular}

Source: Prepared by the authors.

Note: Some estimations correspond to a smaller number of countries owing to a lack of data on the explanatory variables. Twenty-four countries report data for the gini variable: Argentina, Armenia, Belarus, Brazil, Colombia, Costa Rica, Dominican Republic, Ecuador, El Salvador, Georgia, Honduras, Kazakhstan, Mexico, Panama, Paraguay, Peru, the Plurinational State of Bolivia, Republic of Moldova, Russian Federation, Serbia, Thailand, Turkey, Ukraine and Uruguay. The following countries are missing for the following variables: sub: Bahamas, Bahrain, Burundi, Democratic Republic of the Congo, Hong Kong (SAR of China), Libya, Papua New Guinea, Qatar, Singapore and Sudan; eci and corceci, Bahamas, Brunei Darussalam, Burundi, Democratic Republic of the Congo, the Gambia, Guinea-Bissau, Guyana, Sierra Leone and Suriname; gdpind, gdpagro, gdpser, corind, coragro and corser, Angola, Bahrain, Kuwait, Liberia and Libya; fdii, Cuba; cre, Cuba and Iran; tech, Angola, Democratic Republic of the Congo, Guinea-Bissau, Liberia and Libya; water, Brunei Darussalam, Hong Kong (SAR) and Libya; hc, Azerbaijan, Bahamas, Belarus, Cuba, Democratic Republic of Congo, Georgia, Guinea, Guinea-Bissau, Guyana, Lebanon, Libya, Oman, Papua New Guinea and Suriname; ores_metal, Liberia. Standard error in parentheses ${ }^{\star \star *} p<0.01,{ }^{\star *} p<0.05,{ }^{\star} p<0.1$. 


\section{Annex A3}

Table A3.1

Control estimations, GDP per capita as dependent variable, 2002-2014

\begin{tabular}{|c|c|c|c|c|}
\hline \multirow{2}{*}{ Variables } & \multicolumn{2}{|c|}{ Partial } & \multicolumn{2}{|c|}{ Complete } \\
\hline & (C1) & (C1) & (C2) & (C3) \\
\hline \multirow{2}{*}{$\operatorname{loggdp}_{(t-1)}$} & $0.867^{\star \star \star}$ & $0.856^{\star \star \star}$ & $0.963^{\star \star \star}$ & $0.931^{\star \star \star}$ \\
\hline & $(0.0497)$ & $(0.145)$ & $(0.0483)$ & $(0.0342)$ \\
\hline \multirow[t]{2}{*}{ controlcorrup } & $0.225^{*}$ & 0.401 & -2.153 & $0.241^{\star \star}$ \\
\hline & $(0.125)$ & $(0.576)$ & $(1.387)$ & $(0.117)$ \\
\hline \multirow{2}{*}{ controlcorrup $_{(t-1)}$} & 0.120 & $0.591^{*}$ & & \\
\hline & $(0.177)$ & $(0.315)$ & & \\
\hline \multirow[t]{2}{*}{ corceci } & & & & $-1.169^{\star}$ \\
\hline & & & & $(0.627)$ \\
\hline \multirow[t]{2}{*}{ coragro } & & -0.0335 & & \\
\hline & & $(0.0481)$ & & \\
\hline \multirow[t]{2}{*}{$\operatorname{coragro}_{(t-1)}$} & & $-0.0512^{\star \star \star}$ & & \\
\hline & & $(0.0192)$ & & \\
\hline \multirow[t]{2}{*}{ corser } & & & $0.0382^{*}$ & \\
\hline & & & $(0.0231)$ & \\
\hline \multirow[t]{2}{*}{ eci } & 0.0203 & & & $0.411^{*}$ \\
\hline & $(0.0289)$ & & & $(0.224)$ \\
\hline \multirow[t]{2}{*}{$e c i_{(t-1)}$} & $0.0633^{\star \star \star}$ & & & \\
\hline & $(0.0242)$ & & & \\
\hline \multirow[t]{2}{*}{ gdpind } & & -0.00331 & 0.00124 & \\
\hline & & $(0.0120)$ & (0.00759) & \\
\hline \multirow[t]{2}{*}{$\operatorname{gdpind}_{(t-1)}$} & & 0.00221 & & \\
\hline & & $(0.0122)$ & & \\
\hline \multirow[t]{2}{*}{ gdpagro } & & 0.0188 & & \\
\hline & & $(0.0154)$ & & \\
\hline \multirow[t]{2}{*}{ gdpser } & & & $-0.0225^{\star \star}$ & \\
\hline & & & $(0.0103)$ & \\
\hline \multirow{2}{*}{$\operatorname{gdpser}_{(t-1)}$} & & & $0.0118^{\star \star \star}$ & \\
\hline & & & $(0.00439)$ & \\
\hline \multirow[t]{2}{*}{ fdii } & & $0.00562^{\star \star}$ & $0.00228^{\star *}$ & $0.00575^{\star}$ \\
\hline & & $(0.00280)$ & $(0.00102)$ & $(0.00305)$ \\
\hline \multirow[t]{2}{*}{$h c$} & & 0.144 & $0.0761^{\star \star}$ & 0.0822 \\
\hline & & $(0.189)$ & $(0.0368)$ & $(0.0782)$ \\
\hline \multirow[t]{2}{*}{ water } & & & & 0.00170 \\
\hline & & & & $(0.00493)$ \\
\hline \multirow[t]{2}{*}{ abecom } & & -0.00113 & & \\
\hline & & $(0.00124)$ & & \\
\hline \multirow[t]{2}{*}{ gini } & $0.00349^{\star \star}$ & 0.00306 & $0.00231^{\star \star}$ & $0.00533^{\star \star}$ \\
\hline & $(0.00146)$ & $(0.00484)$ & $(0.00118)$ & $(0.00235)$ \\
\hline ores_metal & $0.000980^{\star *}$ & -0.00268 & -0.000259 & -0.000838 \\
\hline & $(0.000438)$ & $(0.00213)$ & $(0.000519)$ & $(0.000751)$ \\
\hline Constant & $0.889^{\star \star \star}$ & 0.613 & 0.594 & -0.0907 \\
\hline & $(0.316)$ & $(1.263)$ & (0.499) & $(0.612)$ \\
\hline No. of instruments & 27 & 29 & 30 & 20 \\
\hline Sargan Test (Prob>chi²) & 0.9472 & 0.9950 & 0.8644 & 0.4568 \\
\hline Arellano-Bond test (AR2 autocorrelation) & 0.0199 & 0.1284 & 0.0961 & 0.5115 \\
\hline No. of observations & 247 & 237 & 234 & 213 \\
\hline No. of countries & 23 & 22 & 22 & 22 \\
\hline
\end{tabular}

Source: Prepared by the authors.

Note: Some estimations correspond to a smaller number of countries owing to a lack of data on the explanatory variables. Twenty-four countries report data for the gini variable: Argentina, Armenia, Belarus, Brazil, Colombia, Costa Rica, Dominican Republic, Ecuador, El Salvador, Georgia, Honduras, Kazakhstan, Mexico, Panama, Paraguay, Peru, the Plurinational State of Bolivia, Republic of Moldova, Russian Federation, Serbia, Thailand, Turkey, Ukraine and Uruguay. The following countries are missing for the following variables: sub: Bahamas, Bahrain, Burundi, Democratic Republic of the Congo, Hong Kong (SAR of China), Libya, Papua New Guinea, Qatar, Singapore and Sudan; eci and corceci, Bahamas, Brunei Darussalam, Burundi, Democratic Republic of the Congo, the Gambia, Guinea-Bissau, Guyana, Sierra Leone and Suriname; gdpind, gdpagro, gdpser, corind, coragro and corser, Angola, Bahrain, Kuwait, Liberia and Libya; fdii, Cuba; cre, Cuba and Iran; tech, Angola, Democratic Republic of the Congo, Guinea-Bissau, Liberia and Libya; water, Brunei Darussalam, Hong Kong (SAR) and Libya; hc, Azerbaijan, Bahamas, Belarus, Cuba, Democratic Republic of Congo, Georgia, Guinea, Guinea-Bissau, Guyana, Lebanon, Libya, Oman, Papua New Guinea and Suriname; ores_metal, Liberia. Standard error in brackets ${ }^{* \star} p<0.01,{ }^{* \star} p<0.05,{ }^{*} p<0.1$. 